\title{
The Effects of Integrated Information Literacy in Science Curriculum on First-Grade Students' Memory and Comprehension Using the Super3 Model
}

\author{
Lin Ching Chen* \\ Department of E-learning Design \& Management \\ National Chiayi University \\ 85 Wenlong, Mingsuin, Chiayi Hsien, 62113, Taiwan \\ E-mail: lingin@mail.ncyu.edu.tw \\ *Corresponding author
}

\begin{abstract}
The purpose of this study was to investigate the effects of integrated information literacy in first-grade science curriculum on students' science learning. In this quasi-experimental study, two first-grade classrooms from a public elementary school were randomly assigned into the experimental group and control group. The former accepted an inquiry-based science curriculum infused information literacy using the Super3 model, while the latter accepted the traditional lecture-oriented instruction. The instructional unit in both experimental and control groups was taught by the same science teacher and lasted around three weeks, seven periods of time per week. Two tests were designed to test student's memory of factual information and comprehension of scientific concepts. Results from the analyses of covariance showed that the experimental group significantly outperformed their counterparts on two measures of science learning. It is suggested that integrated information literacy instruction could have a positive impact on first-graders' subject content learning and lay a foundation for young children to be lifelong learners.
\end{abstract}

Keywords: Information Literacy; Science; Inquiry Learning; Super3 Model

Biographical notes: Lin Ching Chen is currently a Professor in Department of E-learning Design \& Management, National Chiayi University, Taiwan. She has extensive expertise in the area of information literacy and information technology. She earned her Ed.D. in Educational Technology from University of Florida, U.S.A.

\section{Introduction}

Information literacy is crucial for successful survival in today's knowledge society (American Association of School Librarians, 2009). Many studies suggest that the teaching of information literacy should be integrated into the regular curriculum using inquiry-based learning (Chu, Tse, \& Chow, 2011; Eisenberg, 2007; Kuhlthau, Maniotes, \& Caspari, 2007). Iley (2006), MacDonell (2007) and Eisenberg and Robinson (2007) even advocate teachers giving young learners the opportunities to solve problems in order to improve their information literacy, and lay the foundation for more complex problemsolving situations in their lives. However, the results are not consistent with related studies which investigate the effects of inquiry-based and problem-solving learning on 
students' deep thinking and factual knowledge acquisition (Khalid, 2010; Chang \& Mao, 1998; Minner, Levy, \& Century, 2010).

Thus, the Super 3 model is used as the framework for this study to examine the effectiveness of an inquiry-based approach in guiding young children through problem solving and improving lower- and higher-order learning of subject matters. The Super3 model, created by Eisenberg and Robinson, is selected mainly because there are only three steps in this model, and it is easy for young children to remember and relate to (Eisenberg \& Robinson, 2007). However, there is only a limited amount of research into what constitutes an effective Super3 model, and few empirical studies of this model's effects on subject content learning (Heider, 2009; Lieser, 2005). This study would like to investigate this issue by conducting an experiment in two elementary classrooms, which accept a science curriculum infused information literacy using the Super3 model, and the conventional teaching instruction, respectively. Students' factual knowledge learning and concept understanding are the focuses for this study.

This paper first introduces the reason for integrating information literacy into the school curriculum, and employing inquiry learning in science. Then the methods used and results found in this study are described in detail. Finally, the effects of the integrated information literacy curriculum are discussed, and conclusions as well as recommendations are made for future studies.

\section{Literature Review}

\subsection{Integrating Information Literacy into Instruction}

Since the concept of information literacy was introduced in 1970s, it has been promoted by numerous countries around the world. United Nations Educational, Scientific and Cultural Organization (UNESCO, 2007) even suggests every nation should develop information literacy initiatives in the four key domains of education, health, business, as well as citizenship, so that their citizens can perform competitively and productively in a $21^{\text {st }}$ century global information society. In other words, information literacy is considered as the important basis for lifelong learning in the age of knowledge-based economy. Furthermore, the American Association of School Librarians (AASL) has developed new learning standards, entitled Standards for the 21-Century Learners, which expand the definition of information literacy to multiple literacies, including digital, visual, textual, and technological, which are crucial for all learners to be successful in the present society (AASL, 2009). However, how can we teach our children to be information literates? In which ways the information literacy can be integrated into the school curriculum?

Information literacy is the abilities to recognize, locate, evaluate, use and create effectively the needed information (AASL, 2009; AASL \& AECT, 1998). Since these abilities are not equal to disconnected skills (such as computer skills), AASL (2009), Andretta (2005), Van Cleave (2007) as well as Chu, Tse, and Chow (2011) suggested that information literacy is most effectively taught as an integral part of content learning, because the existing learning situations can provide meaningful environments for students practicing the above abilities. In other words, the course-integrated instruction can improve students' information literacy by delivering instruction at their point of needs and recognize the real needs to link information literacy to the contexts of an assignment or a subject area. 
Furthermore, there is a large body of studies on information literacy finding that information literacy instruction should be integrated across all content areas through inquiry-based or problem-solving learning (Chen \& Horng, 2004, 2005; Chen, 2010; Eisenberg, Lower, \& Spitzer, 2004; Harada \& Yoshina, 2004; Heider, 2009; Kuhlthau, Maniotes, \& Caspari, 2007; Okemura, 2008; Rockman, 2004). Inquiry learning is not a method of doing activities merely; rather, it is an approach to the chosen themes in which the posing of real questions and using a variety of sources of information are positively encouraged by teachers. During inquiry, students work alone or in groups to actively discover, explore, quest, understand, synthesize, and create new deep understanding, while teachers play two key roles that are very different from the instructor role in the conventional teaching situation. Teachers in inquiry learning are facilitators, who motivate students to develop the higher level thinking, and resource specialists, who provide the needed resources for students. Several researchers indicate that this type of learning should be taught as early as in kindergarten or even younger levels (Lambros, 2002; MacDonell, 2007; NRC, 2000). Their reasons are that most young children are naturally curious and want to ask questions. Another reason is that young children need to be exposed to informational texts more often since many upper-level elementary graders cannot construct understanding from informational texts due to lack of chances reading them (Filipenko, 2004; Heider, 2009; Iley, 2006). However, informational texts are used quite frequently in the integrated information literacy instruction. Thus, Kuhlthau, Maniotes, and Caspari (2007) stressed that the most important factor for successful information literacy instruction is assignments or topics designed beyond fact finding to inquiry process.

The Super3 model, developed by Eisenberg and Robinson (2007), is one of the inquiry process models used by practitioners and researchers for integrating information literacy into curriculum for young learners (Lieser, 2005; Lowery, 2005; Wolf, 2003). This model provides a framework for young children (K-2) to learn how to complete a task or make a decision. The Super3 has three phases: Plan, Do and Review. In the Plan phase, students figure out what they are supposed to do and to develop a plan of how to accomplish the task. The sub-skills in this phase include determining what information students need and where they will get the information from. Teachers should give students enough waiting time for posing meaningful questions. Otherwise, students may not assume responsibility for their own learning. In the Do phase, students complete the various activities, including finding the needy sources, reading or viewing the information in the sources, and putting it all together as a finished assignment. Students can apply all of the reading skills learned before such as summarizing, finding keywords, note-taking, etc. In the final Review phase, students self-assess and reflect on their performance during the whole inquiry process in order to improve on future assignments. Students must recognize if the problem has been solved based on the stated criteria, and what they might do differently next time.

Although the Super3 model seems to be implemented easily for young learners, few empirical studies so far have investigated its effects on students learning in subject areas. And which subject content suitable for integrating information literacy by inquiry learning has not been examined entirely neither.

\subsection{Scientific Inquiry}

According to the National Science Education Standards (NRC, 1996), inquiry is an important teaching method in science. It involves various classroom activities, such as posing questions, making observations, examining books and other sources of 
information, analyzing data, and communicating the results. Audet and Jordan (2005) stressed that teachers should lead students to ask questions and make discoveries in search for new understanding of science. Cowan and Cipriani (2009) even introduced their first-graders into scientific inquiry through an arts-integrated, pattern-searching approach to build a deeper understanding of science content and processes. In fact, the scientific inquiry is congruent to the concept of information literacy, because they both emphasize the reasoning and critical thinking. Therefore, we may integrate information literacy into science curriculum through inquiry-based strategy to improve students' learning of subject contents.

National Research Council (2000) underscored that student understanding of inquiry could not develop in isolation from science subject matter. In other words, scientific knowledge still remained important. Several meta-analyses showed that inquiry-based teaching produced positive results on cognitive achievement, process skills, and attitudes toward science (Bredderman, 1982; Hurd, 1998; Khalid, 2010; Minner, Levy, \& Century, 2010; Shymansky, Hedges, \& Woodworth, 1990; Weinstein, Boulanger, \& Walbergs, 1982). Haury (1993) reviewed many related studies and concluded that inquiry-oriented teaching could result in outcomes that included scientific literacy, familiarity with science processes, vocabulary knowledge, conceptual understanding, critical thinking, and positive attitudes toward science. Minner, Levy, and Century (2010) also emphasized that having students actively think about and participate in the investigation process increased their science conceptual learning.

However, Chang and Mao (1998) investigated the effects of an inquiry-based teaching in earth science and found that significant higher achievement scores only at the comprehensive test, not at the factual level. National Research Council (2000) also claimed that inquiry-based teaching may not be appropriate for the goal which was for students to memorize information. In addition, an inquiry-based study conducted by Brickman, Gormally, Armstrong, \& Hallar (2009) discovered greater improvements in inquiry students' science literacy and research skills, but these students gained less selfconfidence in scientific abilities compared to the traditional students. Furthermore, the roots of both inquiry-based and problem-based approaches can be traced back to the progressive movement, especially to John Dewey's belief (Audet \& Jordan, 2005; Delisle, 1997; Savery, 2006). Their common characteristics included learner-centered, active learning, as well as real and ill-structured problems. In fact, similar research results of inquiry learning were also found in the problem-based learning studies (PBL). Reviewing problem-based learning research from the past 30 years, Hung, Jonassen, and Liu (2008) concluded that PBL curricula resulted better knowledge application and clinical reasoning skills, but performed less well in basic or factual knowledge acquisition than traditional curriculum. On the other hand, Strobel and Barneveld (2009) used a qualitative meta-synthesis approach to compare the findings of the meta-analytical research on the effectiveness of PBL. They found that problem-based learning was superior when it came to long-term retention, skill development and satisfaction of students and teachers, while traditional approaches were more effective for short-term retention.

In summary, for lack of thorough and conclusive empirical evidence concerning effects of inquiry-based integrated information literacy in science curriculum on students' science learning, teachers usually rely on their intuition in deciding how to teach science. Therefore, more research should be conducted to explore these questions. 


\section{Research Questions}

The purpose of this study was to investigate the effect of integrated information literacy in first-grade science curriculum on students' science learning. Specific problems related to the purpose were as follows:

1. Does the integrated information literacy instruction have an effect on students' ability to memorize the science content associated with the topic?

2. Does the integrated information literacy instruction have an effect on students' ability to comprehend the scientific concepts associated with the topic?

\section{Methods}

\subsection{Participants}

Participants for the study consisted of two first-grade classes from a public elementary school in an urban area of Taiwan. Each class had 32 students and gender was equally distributed. These students' academic abilities were in average level. Since this study was conducted in the spring semester, the participants have had basic reading and writing ability as well as test-taking skills.

\subsection{Research Design}

This study was a quasi-experimental pre-post design (Gall, Gall, \& Borg, 2006). The two classes were randomly assigned to one treatment and one comparison group. Each group had 32 participants. This instructional unit in both experimental and control groups was taught by the same science teacher, while the former employed the integrated information literacy instruction and the latter used the conventional teaching strategy.

\subsection{Instructional Content}

The instructional content for this study was the unit on Exploring Insects in Our School, based on the first-grade science textbook (Kang Hsuan Educational Publishing Group, 2008). An inquiry-based science curriculum infused information literacy was delivered to the experimental group. It was designed based on the Super3 model. First, the science teacher motivated students to inquire various insects found on campus using relevant nonfiction books and videos, so that they could pose at least three questions relating to the insect selected for inquiring. Students may also take their free time observing the insect on campus in detail. The teacher would clearly explain the criteria upon which students' work would be assessed. Then several final work examples from excellent to bad levels would be provided for students to examine, so that they knew what was expected of them. It was the first part of the Super3 model: Plan phase.

Then, in the phase of Do, under the teacher's guidance, students tried to find the answers to the questions through accessing nonfiction books, videos, and observing insects on campus. Then, they compared all of the information from the different sources and selected the wanted information to be put into a poster. Then they presented it in front of the class. Finally, they reviewed their own performance during the whole process and wrote down their reflection in the journals. It was the Review phase. However, if students could not find suitable answers to the questions, or find other more interesting 
information from the resources, they could always go back to the Plan phase to change their questions. In other words, the Super3 process was not linear or in a restrictive order; instead it allows users getting back to the former phase to make changes (see Figure 1). Overall, this instruction addressed both subject content and information literacy process at the same time. In the whole learning process, the teacher's role was as a guide on the side-lines who encouraged students and provided useful resources and support in poster preparation and oral presentations. The integrated instruction lasted for 3 weeks, 19 periods of time. Each period of time was 40 minutes. Table 1 was the brief instructional design for the experimental group, which listed weeks, periods of time, the Super3 phases, and learning activities.

Table 1. Brief instructional design for the integrated information literacy in science curriculum

\begin{tabular}{|c|c|c|}
\hline Week/period & Super3 & Learning activities \\
\hline $\begin{array}{l}\text { Week } 1 \\
17 \text { periods }\end{array}$ & $\begin{array}{l}\text { Plan } \\
\text { Review }\end{array}$ & $\begin{array}{l}\text { - Students perceived the weather changes in spring. } \\
\text { - Students walked through the campus and observed } \\
\text { insects. } \\
\text { - } \\
\text { - Students learned the Super3 model. } \\
\text { - Students practiced posing good questions. } \\
\text { Students wrote reflection journal. }\end{array}$ \\
\hline Week 2 & $\begin{array}{l}\text { Plan } \\
\text { Do } \\
\text { Review }\end{array}$ & $\begin{array}{l}\text { - } \quad \text { Students posed/revised questions for inquiry. } \\
\text { - } \quad \text { Students reviewed reading comprehension strategies. } \\
\text { - } \quad \text { Students read and view relevant resources. } \\
\text { - } \quad \text { Students wrote reflection journal. }\end{array}$ \\
\hline Week 3 & $\begin{array}{l}\text { Do } \\
\text { Review }\end{array}$ & $\begin{array}{l}\text { - } \\
\text { - } \\
\text { - Students produced an insect poster. } \\
\text { - Students reviewed the product and inquiry process. }\end{array}$ \\
\hline
\end{tabular}

On the other hand, the control group was exposed to the traditional teaching method on the same instructional content used for the experimental group. The traditional teaching method was teacher-centered and lecture oriented. The teacher provided the students with clear and detailed explanation, but did not ask students to raise questions, nor need to find answers through reading, viewing, and observing. The classroom activities mostly focused on memorizing the facts in the unit, such as insect's characteristics. Table 2 was the brief instructional design for the control group, which listed weeks, periods of time, and teaching activities. 


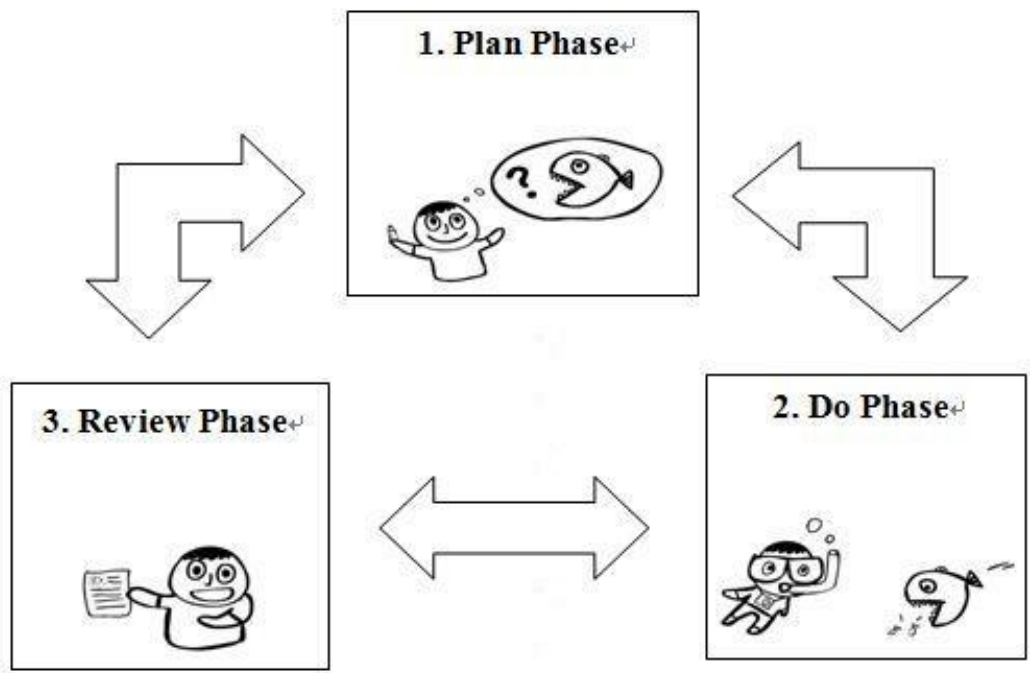

Figure 1. Super3 model

Table 2. Brief instructional design for the conventional science curriculum

\begin{tabular}{|c|c|}
\hline Week/period & Teaching activities \\
\hline $\begin{array}{l}\text { Week } 1 \\
\text { /7 periods }\end{array}$ & $\begin{array}{l}\text { Teacher taught the weather changes in spring. } \\
\text { Teacher led students to walk through the campus. } \\
\text { Teacher led students to discuss the content in the textbook. } \\
\text { Students finished the worksheets in the textbook. }\end{array}$ \\
\hline $\begin{array}{l}\text { Week } 2 \\
/ 7 \text { periods }\end{array}$ & $\begin{array}{l}\text { - Teacher led students to discuss the worksheet. } \\
\text { - Teacher explained the characteristics of insects. } \\
\text { - Teacher taught students to make a mosaic picture of an insect. }\end{array}$ \\
\hline $\begin{array}{l}\text { Week } 3 \\
15 \text { periods }\end{array}$ & $\begin{array}{l}\text { Teacher taught the content in the textbook. } \\
\text { - Students finished the worksheets in the textbook. } \\
\text { - Teacher explained the worksheets. }\end{array}$ \\
\hline
\end{tabular}

\subsection{Research Instruments}

There were two instruments used in this study. They were memory test and comprehension test. The former was designed to test students' memory of subject content which was taught in the instruction. There were 20 multiple-choice items in the test. Each item was 1 point, and the highest point was 20 . Its reliability level was KR21 $=0.721$, difficulty level 0.66 , discrimination level 0.48 . 
The comprehension test was composed of 14 constructed-response questions which assessed students' observation ability, in-depth reasoning and application of underlying concept in novel situations. It required students to write their own answers. Some items required short answers while others demanded to circle the differences in two pictures of insects. In scoring the comprehension test, correct answers to the questions were worth one to five points. Thus, the total number of score points available for analyses ( 23 points) exceeds the number of items in the assessment. Its reliability level was KR2 $1=0.838$, difficulty level 0.62 , discrimination level 0.6.

\subsection{Procedure}

Two first-grade classrooms from a public elementary school were selected and randomly assigned to the experimental group and control group. Then they received two pretests (memory and comprehension tests) to determine their prior knowledge level in the instructional content. Next, the experimental group accepted an inquiry-based science curriculum infused information literacy using the Super3 model, while the control group accepted the traditional instruction. The instruction lasted for three weeks and was taught by the same science teacher. Upon the completion of the instruction, both groups received two posttests (the same memory and comprehension tests).

\subsection{Data Analysis}

The data was analyzed using an analysis of covariance (ANCOVA) on posttest scores with the pretest as the covariate to determine any significant differences between the experimental group and the control group.

\section{Results}

\subsection{Analysis of Memory Test Results}

The memory test means, standard deviations and adjusted mean were presented in Table 3. Summary ANCOVA statistics were shown in Table 4. As shown in Table 4, the obtained $\mathrm{F}$ ratio was significant $(\mathrm{F}=69.747, \mathrm{p}<0.05)$. The inquiry-based science curriculum infused information literacy can improve first-grader's memory achievement than the traditional lecture-led method.

Table 3. Pretest Mean, Posttest Mean, Adjusted Mean in Memory Test

\begin{tabular}{ccccccc}
\hline \multirow{2}{*}{ Group } & \multirow{2}{*}{$\mathrm{N}$} & \multicolumn{2}{c}{ Pretest } & \multicolumn{2}{c}{ Posttest } & \multirow{2}{*}{ Adjusted M } \\
\cline { 3 - 6 } & & Mean & $\mathrm{SD}$ & Mean & SD & \\
\hline Experiment Group & 32 & 12.56 & 4.15 & 18.37 & 1.476 & 18.762 \\
\hline Control Group & 32 & 14.56 & 2.37 & 15.06 & 2.285 & 14.675 \\
\hline
\end{tabular}


Table 4. Summary of Analysis of Covariance in Memory Test

\begin{tabular}{cccccc}
\hline Source & $S S$ & $d f$ & $M S$ & F & $\mathrm{p}$ \\
\hline Treatment & 281.736 & 1 & 140.868 & $69.747^{*}$ & .000 \\
\hline Error & 123.201 & 61 & 2.020 & & \\
\hline$* p<.05$ & & & & &
\end{tabular}

\subsection{Analysis of Comprehension Test Results}

The comprehension test means, standard deviations and adjusted mean were presented in Table 5. Summary ANCOVA statistics were shown in Table 6. As shown in Table 6, the obtained $\mathrm{F}$ ratio was significant $(\mathrm{F}=49.982, \mathrm{p}<0.05)$. The inquiry-based science curriculum infused information literacy can improve first-grader's comprehension achievement than the traditional lecture-led method.

Table 5. Pretest Mean, Posttest Mean, Adjusted Mean in Comprehension Test

\begin{tabular}{ccccccc}
\hline \multirow{2}{*}{ Group } & \multirow{2}{*}{$\mathrm{N}$} & \multicolumn{2}{c}{ Pretest } & \multicolumn{2}{c}{ Posttest } & \multirow{2}{*}{ Adjusted M } \\
\cline { 3 - 6 } & & Mean & SD & Mean & SD & \\
\hline Experiment Group & 32 & 10.34 & 4.63 & 15.375 & 2.70 & 15.780 \\
\hline Control Group & 32 & 12.19 & 3.26 & 13.188 & 2.25 & 12.782 \\
\hline
\end{tabular}

Table 6. Summary of Analysis of Covariance in Comprehension Test

\begin{tabular}{cccccc}
\hline Source & $S S$ & $d f$ & $M S$ & F & $\mathrm{p}$ \\
\hline Treatment & 268.446 & 1 & 134.223 & $42.982 *$ & .000 \\
\hline Error & 190.491 & 61 & 3.123 & & \\
\hline$* p<.05$ & & & &
\end{tabular}

\section{Discussion}

The data analyses of this study showed that the experimental group performed significantly better than their counterparts on memory and comprehension tests. In other words, the integrated information literacy curriculum using the Super3 model can help first-graders not only memorize factual scientific information, but also gain a deep understanding of scientific concepts. These results support previous research, such as Khalid (2010), Minner, Levy, and Century, 2010, Shymansky, Hedges, \& Woodworth (1990), Bredderman (1982), Hurd (1988), and Haury (1993).

It is not easy to explain to young students about process, let alone teach them to become better thinkers and problem-solvers. As Eisenberg and Robinson (2007) said, "Learning problem-solving skills does not begin in college. Every day, even very young children tackle tasks, make decisions, and solve problems both on an academic and personal level." (p. 5) Through the Super3 model in this study, students in experimental group selected their favorite insects for inquiry, such as bees, ants, butterflies, and 
ladybugs. The teacher provided students with relevant nonfiction books and videos in the learning environment, and encouraged them to observe the insects on campus. At the same time, the students had to compared and extract the needed information from various resources to answer the stated questions. Therefore, they were exposed to an inquiring environment, as NRC (1996, 2000) described, where students posed questions, making observation, examining information, interpreting data and communicating results. Thus, the finding in comprehension learning of this study verified what many studies have stated that integrating information literacy into curriculum through inquiry-based strategies did help develop higher-order thinking skills (Andrews \& Patil, 2007; Haury, 1993; Hung, Jonassen, \& Liu, 2008; Khalid, 2010).

In terms of memory learning, the finding of this study was different from Chang and Mao (1998), as well as Hung, Jonassen, and Liu (2008). A possible reason may have been that the Super3 model highlighted both factual knowledge acquisition and knowledge application during the inquiry process. Owing to the first-graders' reasoning skills was still developing, though they did have a "questioning mind", most of the questions they posed were memory-based level, such as "What did ants eat?" and "Where did bees live?" Thus, during the inquiry process, the students gathered and extracted the needed information from various resources to solve the problems, what they read and viewed repeatedly were all factual knowledge. If the questions they posed were higherorder ones (e.g., cause-and-effect questions, convergent thinking questions, divergent thinking questions, evaluative thinking questions) (Audet \& Jordan, 2005; Ciardiello, 1998), students' memory performance in the experimental group may be less well than in the control group. However, this assumption needs more research to verify it.

\section{Conclusion}

From the results of this study, the integrated information literacy instruction in first-grade science curriculum using the Super3 model could improve students' learning on memory and comprehension levels. In other words, the Super 3 model has positive effects on subject content learning. As young as first-grade children, they are able to possess critical thinking skills if the information literacy instruction can be effectively integrated into the school regular curriculum. Based on the findings of this study, the following implications and recommendations are made for the future research:

1. Integrated information literacy science curriculum can improve students' factual knowledge and higher-order thinking skills.

2. Science teachers should design more inquiry-based curricula infused information literacy using the Super3 model as early as possible, so that young children is used to this learning strategy, and become lifelong learners later.

3. Since this study focused on the subject content learning, rather than the information literacy skills, future studies may investigate this aspect.

4. Further empirical studies can be carried out on the relationship among age, types of questions, and inquiry learning.

\section{Acknowledgements}

This research was supported in part by the National Science Council in Taiwan (Grant No. NSC99-2420-H-415-003). 


\section{References}

1. American Association of School Librarians (AASL). (2009). Standards for the 21st-century learner in action. Chicago, IL: American Association of School Librarians.

2. American Association of School Librarians (AASL), \& Association for Educational Communications and Technology (AECT). (1998). Information literacy standards for student learning. Chicago, IL: American Library Association.

3. Andretta, S. (2005). Information literacy: A practitioner's guide. Oxford, UK: Chandos.

4. Andrews, T., \& Patil, R. (2007). Information literacy for first-year students: An embedded curriculum approach. European Journal of Engineering Education, 32(3), 253-259.

5. Audet, R., \& Jordan, L. (2005). Integrating inquiry across the curriculum. Thousand Oaks, CA: Corwin Press.

6. Bredderman, T. (1982). Elementary school science process programs: A metaanalysis of evaluation studies. (Final report of NSF-RISE Grant SED 18717)

7. Brickman, P., Gormally, C., Armstrong, N., \& Hallar, B. (2009). Effects of inquiry-based learning on students' science literacy skills and confidence. International Journal for the Scholarship of Teaching and Learning, 3(2), 1-22.

8. Chang, C.Y., Mao, S.L. (1998). The effects of an inquiry-based instructional method on earth science students' achievement. Paper presented at the Annual Meeting of the National Association for Research in Science Teaching. San Diego, CA. (ERIC Document Reproduction Service No. ED 418 858)

9. Chen, L.C., \& Horng, M.L. (2004). Integrating information literacy into the fifthgrade social studies curriculum: An example of electing a right person. Journal of Library and Information Science, 30(1), 26-40.

10. Chen, L.C., \& Horng, M.L. (2005). Integrating information literacy into elementary social studies: An example of Chinese culture. Journal of Library and Information Science, 31(2), 108-130.

11. Chen, L.C. (2010). Using debate in the 6th grade social studies: Promoting student information literacy. Journal of Educational Media \& Library Science, 47(4), 499530.

12. Chu, S.K., Tse, S.K., \& Chow, K. (2011). Using collaborative teaching and inquiry project-based learning to help primary school students develop information literacy and information skills. Library \& Information Science Research, 33(2), 132-143.

13. Ciardiello, A.V. (1998). Did you ask a good question today? Alternative cognitive and metacognitive strategies. Journal of Adolescent \& Adult Literacy, 42(3), 210220.

14. Cowan, K.W., \& Cipriani, S. (2009). Of water troughs and the sun: Developing inquiry through analogy. Young Children, 64(6), 62-67.

15. Delisle, R. (1997). How to use problem-based learning in the classroom. Alexandria, VI: Association for Supervision and Curriculum Development.

16. Eisenberg, M.B. (2007). Teaching information literacy: Context, context, context. In S. Curzon \& L. Lampert (Eds.), Proven strategies for building an information literacy program (pp.163-175). New York: Neal-Schuman Publishers. 
17. Eisenberg, M.B., \& Robinson, G.A. (2007). The Super3: Information skills for young learners. Worthington, $\mathrm{OH}$ : Linworth.

18. Eisenberg, M.B., Lowe, C.A., \& Spitzer, K.L. (2004). Information literacy: Essential skills for the information age. Westport, CT: Libraries Unlimited.

19. Filipenko, M. (2004). Construction knowledge about and with informational texts: Implications for teacher-librarians working with young children. School Libraries Worldwide, 10(12), 21-36.

20. Gall, M.D., Gall, J.P., \& Borg, W.R. (2006). Educational research: An introduction. New York: Allyn \& Bacon.

21. Harada, V., \& Yoshina, J. (2004). Inquiry learning through librarian-teacher partnerships. Worthington, OH: Linworth.

22. Haury, D.L. (1993). Teaching science through inquiry. ERIC CSMEED Digest (ERIC Document Reproduction Service No. Ed 359 048).

23. Heider, K.L. (2009). Information literacy: The missing link in early childhood education. Early Childhood Education Journal, 36(6), 513-518.

24. Hung, W., Jonassen, D., \& Liu, R. (2008). Problem-based learning. In J. M. Spector, M. D. Merrill, J. Merrienboer \& M. P. Driscoll (Eds.), Handbook of research on educational communications and technology (pp. 485-506). New York: Lawrence Erlbaum Associates.

25. Hurd, P.D. (1998). Scientific literacy: New minds for a changing world. Science Education, 82, 407-416.

26. Iley, P. (2006). Using literacy to develop thinking skills with children aged 5-7. Abingdon, Oxon: David Fulton.

27. Kang Hsuan Educational Publishing Group. (2008). Science education handbook for grade 1. Taipei: Kang Hsuan Educational Publishing Group.

28. Khalid, T. (2010). An integrated inquiry activity in an elementary teaching methods classroom. Science Activities, 47, 29-34.

29. Kuhlthau, C., Maniotes, L., \& Caspari, A. (2007). Guided inquiry: Learning in the 21 st century. Westport, CT: Libraries Unlimited.

30. Lambros, A. (2002). Problem-based learning in K-8 classrooms: A teacher's guide to implementation. Thousand Oaks, CA: Corwin Press.

31. Lieser, E. (2005). Building native American houses using the Super 3: A collaborative unit. Library Media Connection, 24(2), 42-45.

32. Lowery, J. (2005). Information literacy and writing: Natural partners in the library media center. Knowledge Quest, 34(2), 13-15.

33. MacDonell, C. (2007). Project-based inquiry units for young children: First steps to research for grade pre- $K-2$. Worthington, $\mathrm{OH}$ : Linworth.

34. Minner, D.D., Levy, A.J., Century, J. (2010). Inquiry-based science instructionwhat is it and does it matter? Results from a research synthesis years 1984-2002. Journal of Research in Science Teaching, 47(4), 474-496.

35. National Research Council (NRC). (1996). National science education standards. Washington, DC: National Academy Press.

36. National Research Council (NRC). (2000). Inquiry and the national science education standards: A guide for teaching and learning. Washington, DC: National Academy Press. 
37. Okemura, A. (2008). Designing inquiry-based science units as collaborative partners. School Library Media Activities Monthly, 25(3), 47-51.

38. Rockman, I. (2004). Introduction: The importance of information literacy. In I. Rockman (Ed.), Integrating information literacy into the higher education curriculum: Practical models for transformation (pp.1-28). San Francisco, CA: Jossey-Bass.

39. Savery, J.R. (2006). Overview of problem-based learning: Definition and distinctions. The Interdisciplinary Journal of Problem-Based Learning, 1(1), 9-20.

40. Shymansky, J.A., Hedges, L.V., \& Woodworth, G.. (1990). A reassessment of the effects of inquiry-based science curriculum of the ' 60 s on student performance. Journal of Research in Science Teaching, 27, 127-144.

41. Strobel, J., \& Barneveld, A. (2009). When is PBL effective? A meta-synthesis of meta-analyses comparing PBL to conventional classrooms. The Interdisciplinary Journal of Problem-Based Learning, 3(1), 44-58.

42. United Nations Educational, Scientific and Cultural Organization (Ed.). (2007). Understanding information literacy: A primer. Paris: United Nations Educational, Scientific and Cultural Organization.

43. Van Cleave, K. (2007). Collaboration. In S. Curzon \& L. Lampert (Eds.), Proven strategies for building an information literacy program (pp. 177-191). New York: Neal-Schuman.

44. Weinstein, T., Boulanger, F.D., \& Walberg, H.J. (1982). Science curriculum effects in high school: A quantitative synthesis. Journal of Research in Science Teaching, 19(6), 511-522.

45. Wolf, S. (2003). The Big6 information skills as a metacognitive scaffold: A case study. School Library Media Research, 6(1), 10-14. 